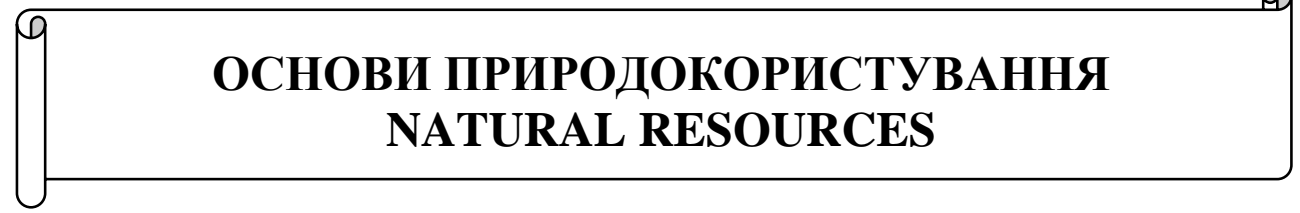

УДК 504.062+556:528.8

Oleksandr M. Trofymchuk ${ }^{1}$, Corresponding member of NASU, D. S. (Engineering), Professor, Director of the Institute ORCID ID 0000-0003-3782-4209 e-mail: itelua@kv.ukrtel.net

Gryhorii Ya. Krasovsky2, D. S. (Engineering), Professor, Head of the Department

Valentyn V. Radchuk 1 , D. S. (Geology), Head of the Department

Vasil M. Trysnyuk ${ }^{1}$, D. S., Head of the Department of environment research ORCID ID: 0000-0001-9920-4879e-mail:trysnyuk@ukr.net

Igor V. Radchuk ${ }^{1}, \mathrm{PhD}$, Senior Research Scientist

ORCID ID: 0000-0003-4999-1258 e-mail: igor.radchuk.v@gmail.com

Dmytro L. Kreta ${ }^{1}, \mathrm{PhD}$, Senior Research Scientist

ORCID ID 0000-0001-5897-0008 e-mail: dim.leo@gmail.com

Snizhana A. Zagorodnya ${ }^{1}, \mathrm{PhD}$, Senior Research Scientist

ORCID ID: 0000-0002-4332-4211 e-mail: zagorodnya.s@gmail.com

Natalia A. Sheviakina ${ }^{1}$, PhD, Senior Research Scientist

ORCID ID: 0000-0002-5984-5580 e-mail: novokhatska.natalia@gmail.com

Viacheslav O. Okhariev ${ }^{1}$, PhD, Senior Research Scientist

ORCID ID: 0000-0001-6270-6293 e-mail: okhariev.vo@gmail.com

Taras V. Trysnyuk ${ }^{1}, \mathrm{PhD}$, Senior Research Scientist

ORCID ID: 0000-0002-3672-8242 e-mail: trysnyuk@ukr.net

Viktor O. Shumeiko ${ }^{1}, \mathrm{PhD}$, Lecturer

ORCID ID: 0000-0002-0285-4566 e-mail: shym1983@ukr.net

Oleksandr V. Atrasevych ${ }^{1}$, Postgraduate student

ORCID ID: 0000-0001-7703-8494 e-mail:atras@ukr.net

Viacheslav Y. Vishnyakov ${ }^{3}, \mathrm{PhD}$, Head of the Department

ORCID ID: 0000-0003-2057-0505e-mail:wishnya_dzz@ukr.net

${ }^{1}$ Institute of Telecommunication and Global Information Space of NASU, Kyiv, Ukraine

${ }^{2}$ National Aerospace University «Kharkiv Aviation Institute», Kharkiv, Ukraine

${ }^{3}$ Center for Special Information Reception and Processing and Navigation Field Control, Zalistsi Village, Dunaivtsi district, Khmelnitskyi Region, Ukraine 


\title{
FIELD RESEARCH OF ECOLOGICAL PARAMETERS IN BAKOTA BAY AREA
}

\begin{abstract}
Problem of hydrological research is conditioned by significant part of water reservoirs in landscape space of Ukraine. Nowadays there is an intensified natural and anthropogenic transformation in the local and regional levels of landscape. The problem that have scientific and economic significance is complex environmental assessment with creating of composite ecological indicators and research of hydrological ecosystems regularity. It this paper authors have determined regularities of the anthropogenic impact to ecological situation in the freshwater reservoirs of Ukraine. Also there were developed such scientific approaches as remote sensing methods, bathymetry, 3D-modelling of aquatic areas, water eutrophication researches. The theme of the paper is a review of the hydrological ecosystem field research. Research area is Bakota Bay in Dniester Canyon and adjacent territories. Main purpose of research is to evaluate potential reaction of environment to direct or indirect anthropogenic impact, as well as to solve problem of sustainable nature management according to expected state of environment. During the research of surface water in Dniester water area, a number of hydrophysical indicators have taken into account, as temperature fluctuations boundary, color, transparency, hydroacoustic and geomorphological data of the bottom relief in water area. Also some navigational hazards and sunken objects have determined.

As a result of research, some scientific approaches and methods have reasoned. For researched local geosystem, the anthropogenic impact assessment is grounded on distributed in space in time environmental monitoring data. Specifically, it consists of the synthesis of contact and remote monitoring methods. Spatially-distributed nature of monitoring data allows using the power of actual GIS-technologies, which provide a large variety of multidimensional spatial analyst tools for various pollution factors evaluation. Authors insist that echolocation-based bathymetry is important method for solving problems of water resource management on researched area, which has international importance in the frame of planned Dniester Canyon hydro power cascade construction.
\end{abstract}

Keywords: field research; environmental safety; influence assessment; water objects; remote sensing methods; geographical information systems

\section{О.М. Трофимчук ${ }^{1}$ Г.Я. Красовський ${ }^{2}$, В.В. Радчук 1 , В.М. Триснюк ${ }^{1}$, І.В. Радчук ${ }^{1}$, Д.Л. Крета ${ }^{1}$, С.А. Загородня ${ }^{1}$, Н.А. Шевякіна ${ }^{1}$, В.О. Охарсв ${ }^{1}$, Т.В. Триснюк ${ }^{1}$, В.О. Шумейко ${ }^{1}$, О.В. Атрасевич ${ }^{1}$, В.Ю. Вишняков ${ }^{3}$}

${ }^{1}$ Інститут телекомунікацій і глобального інформаційного простору НАН України, м. Київ, Україна

${ }^{2}$ Національний аерокосмічний університет ім. М.Є. Жуковського, м. Харків, Україна ${ }^{3}$ Центр прийому і обробки спеціальної інформації та контролю навігаційного поля, с. Залісці Дунаєвецького р-ну Хмельницької обл., Україна

\section{ЕКСПЕДИЦЙНІ ДОСЛІДЖЕННЯ ПАРАМЕТРІВ ЕКОЛОГІЧНОГО СТАНУ ЗАТОКИ БАКОТА}

Анотація. Стаття присвячена огляду результатів проведених експедиційних досліджень водних екосистем Дністровського каньйону, а саме затоки Бакота та прилеглих територій. Основною метою досліджень є оиінка можливої реакиї навколищнього природного середовища на прямий чи опосередкований антропогенний вплив, а також вирімення задач раціонального

(C) O.M. Trofymchuk, G.Ya. Krasovsky, V.V. Radchuk, V.M. Trysnyuk, I.V. Radchuk, D.L. Kreta, S.A. Zagorodnya, N.A. Sheviakina, V.O. Okhariev, T.V. Trysnyuk, V.O. Shumeiko, O.V. Atrasevych, V.Y. Vishnyakov, 2019 
природокористування у відповідності з очікуваним станом природного середовища. При проведенні досліджень поверхневих вод р. Дністер та затоки Бакота враховано низку гідрофізичних показників: межі коливання температури, кольоровості, прозорості, збирання гідроакустичних $i$ геоморфологічних даних про рельєф дна в акваторіях та виявлення навігаційних небезпек та затонулих об'єктів.

Ключові слова: експедиційні дослідження; екологічна безпека; оцінка впливу; водні об'єкти; методи дистанційного зондування Землі; географічні інформаційні системи

\section{Вступ}

Забезпечення безпеки життєдіяльності населення, збереження навколишнього середовища в умовах кліматичних змін та зростання антропогенної діяльності в басейнах річок обумовлюють вирішення складних задач 3 прогнозування загроз надзвичайних ситуацій на прирічкових територіях, які відіграють визначальну роль в забезпеченні екологічної рівноваги в межах річкових басейнів. Водні об'єкти природно-заповідного фонду мають виключно важливе значення у формуванні ландшафту, функціонуванні природних біоценозів, збереженні генофондів наземних, напівводних та водних представників флори і фауни. Розвиток інтегрованої системи гідрофізичного, геологічного, екологічного дослідження, моніторингу та прогнозу стану водних об'єктів України та їх прибережних територій $є$ актуальним для вирішення найгострішої проблеми сьогодення - дефіциту питної води.

Сучасні підходи, реалізовані в середовищі геоінформаційних систем, $\epsilon$ ефективним інструментом оперативного аналізу i прогнозу динаміки антропогенних, природних i соціальних факторів. На сьогодні виникає необхідність розвитку методології моніторингу об'єктів навколишнього середовища шляхом інтеграції міждисциплінарних методів аналізу даних дешифрування космознімків i лабораторно-польових вимірювань, ідентифікації інтегральних параметрів і встановлення причинно-наслідкових зв'язків виникнення екологічних загроз для екологічно безпечного управління екосистемами. Будь-які фундаментальні та прикладні наукові дослідження все більше потребують наочності в поданні їх результатів. Існує достатня кількість програмних пакетів, що дозволяють моделювати навколишнє середовище 3 високим ступенем достовірності і фотореалістичним графічним втіленням. Але оскільки досліджувані процеси і системи мають чітку просторову прив'язку, виникає необхідність всебічної інтеграції такого програмного забезпечення із сучасними геоінформаційними технологіями.

\section{Результати та їх обговорення}

Співробітниками Інституту телекомунікацій і глобального інформаційного простору НАН України в літній та осінній періоди 2018 року проводились експедиційні дослідження водних об'єктів Національного природного парку «Подільські Товтри», а саме затоки Бакота, здійснення батиметричної зйомки та дослідження екологічного стану прилеглих територій. Затока виникла у 1981 році після затоплення низинної ділянки р. Дністер у процесі заповнення Дністровського водосховища (рис. 1). Назва затоки походить від затопленого села Бакота. 


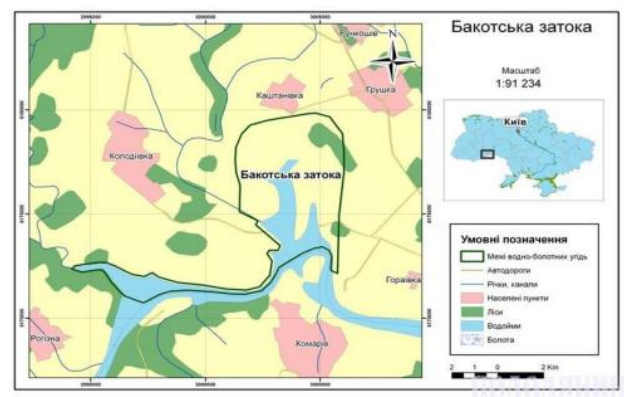

a) Топографічна карта 1989 p.

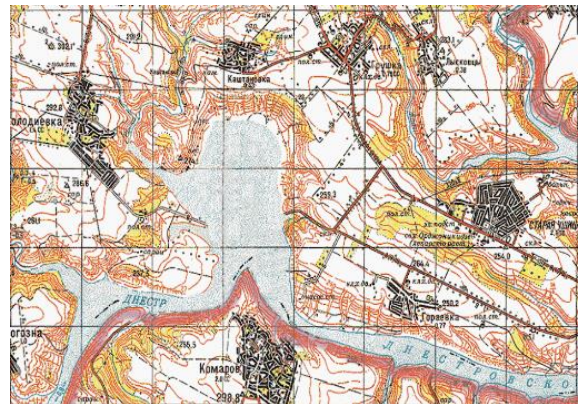

б) Топографічна карта генштабу

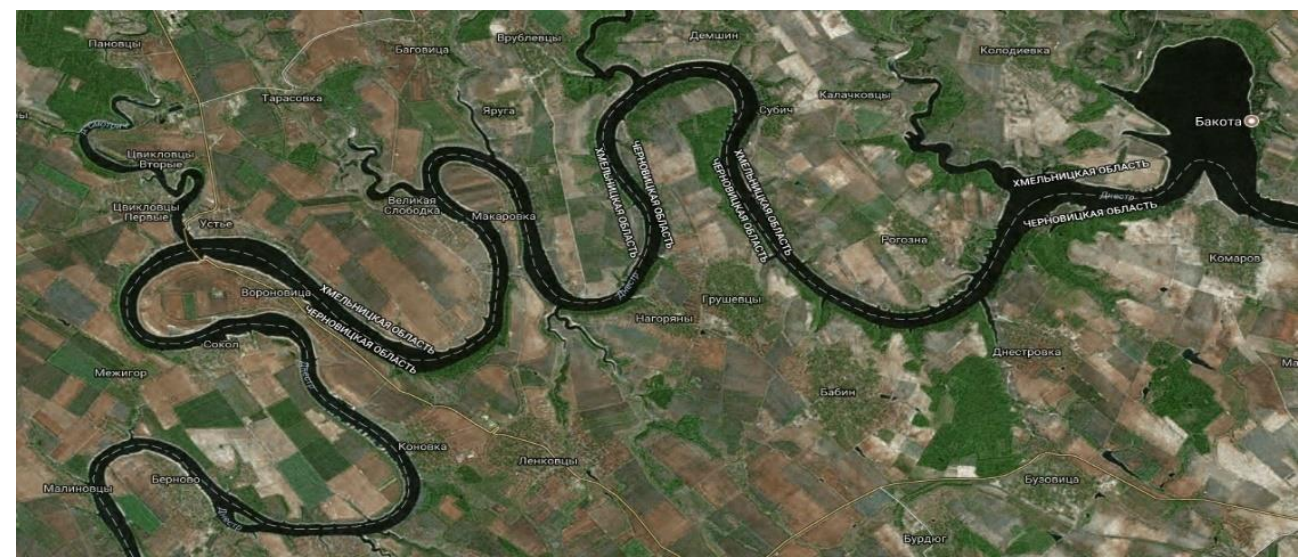

в) Космічний знімок LANDSAT

Рис. 1 - Аналіз різночасових картографічних даних (а, б) та даних ДЗ3 (в) русла р. Дністер

Мета експедиційних досліджень - збір первинних даних на території НПП "Подільські Товтри" для забезпечення послідовності і безперервності досліджень екосистеми Дністровського каньйону, використовуючи сучасні методи і технології тематичного дешифрування космічних знімків водних об'єктів. Побудова батиметричних карт водних об'єктів як джерел комплексного водокористування.

Бакотська затока - водно-болотне угіддя міжнародного значення, що охороняється згідно з Рамсарською конвенцією [1]. Збереження природних цінностей угіддя забезпечується його входженням до складу Національного природного парку «Подільські Товтри». Територія національного природного парку належить до Західно-Подільської височинної області. Окрасою цієї території $\epsilon$ Товтровий кряж, або «Товтри», який являє собою скелясте дугоподібне пасмо Західного Поділля. Довжина Товтр сягає 250 км (80 км у межах національного парку), ширина - 5-6 км, а абсолютні висоти коливаються від 400 до 436 м. Товтри являють собою бар'єрний риф міоценового моря, складений мшанковими, мембранопоровими та черепашковими вапняками. Аналогів їм у світі немає.

Відповідно до Рамсарської конвенції, специфіка збереження і збалансованого використання водно-болотних екосистем, цінних для збереження біологічного різноманіття та забезпечення існування людини, диктує доцільність синтезу проблемно-орієнтованих геоінформаційних 
моделей в якості складових бази даних Державного кадастру природнозаповідного фонду України. Також актуальним завданням є оцінка стану екосистеми за такими параметрами, як забруднення земельних ресурсів та якість поверхневих i підземних вод, що $\epsilon$ важливою складовою водозабезпечення території України [2, 3].

Дослідження водного об'єкта було розпочате з вивчення водозбірної площі. «Бакота»- це затока р. Дністер; висота над рівнем моря: мінімальна -114 м, середня - 117,5 м, максимальна - 121 м. Площа: 1590 га. Розташована в каньйоні річки і репрезентує типові для басейну верхнього Дністра природні комплекси рослинності і тваринного світу $[1,2]$.

Обстеження берегової лінії затоки Бакота проведено при обході її по всьому периметру на човні (рис. 2). При цьому були досліджені обриси і форми берегів, склад берегів, наявність терасових виступів і берегових валів. По периметру берегової лінії водного об'єкта зафіксовані вапняки, мергелі, пісковики, сланці, а також граніти та гнейси, що перекриваються лесами. Відзначається близьким до поверхні заляганням порід кристалічного фундаменту. Поверхня берегів - це переважно підвищена полого-хвиляста лесова рівнина.
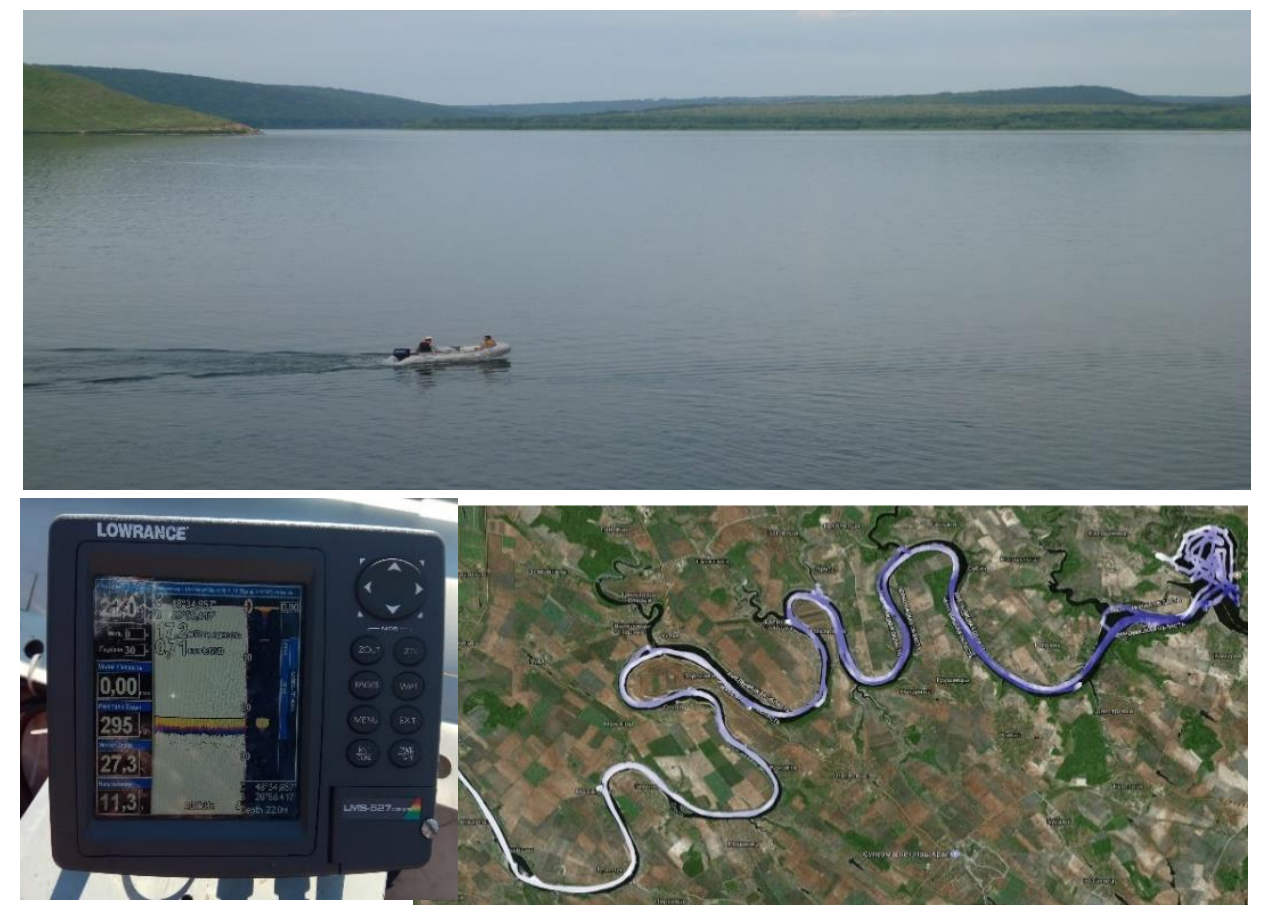

Рис. 2 - Обстеження берегової лінії затоки Бакота проведено при обході їі по всьому периметру на човні

Ефективність контактних методів моніторингу поверхневих вод можна підвищити за рахунок застосування технологій дистанційного зондування Землі (Д33) з космосу [4, 5]. Для виконання досліджень було отримано космічні знімки SENTINEL 14.08.2018, MODIS, LANDSAT, QUICK BIRD та iн. 3 просторово-роздільною здатністю від декількох дециметрів до декількох сотень метрів, які мають значний потенціал у сенсі їх використання для 
вивчення багаторічної динаміки природних комплексів [6]. Для досліджень використовувались як архіви космічних знімків супутників, так і знімки за період проведення безпосередніх польових досліджень [7, 8]. При цьому використано функціонал сучасних технологій геоінформаційних систем (ГІС), що надають потужні інструменти багатовимірного просторового аналізу впливовості різних факторів забруднення [9].

При проведенні досліджень поверхневих вод р. Дністер та затоки «Бакота» враховано низку гідрофізичних показників: межі коливання температури, кольоровості, прозорості, каламутності (зважені частинки). В цілому хімічні характеристики досліджуваних вод включають загальні показники й показники вмісту неорганічних речовин: величину $\mathrm{pH}$, суму іонів (мінералізація), жорсткість, вміст окремих елементів сольового та біогенного складу [4].

Комплекс показників екологічної класифікації якості поверхневих вод включає загальні й специфічні показники, що характеризують ступінь забрудненості водного об'єкта. Вихідними даними для екологічної оцінки якості води $\epsilon$, насамперед, зведені й розрізнені результати систематичного контролю за якістю води у водних об'єктах України, котрі зібрані й оброблені мережею пунктів спостережень i лабораторій систем Мінприроди, Держгідрометслужби та Держводгоспу України. Загальні показники, до яких належать показники сольового складу й трофо-сапробності вод (екологосанітарні), характеризують звичайні властиві водним екосистемам інгредієнти, концентрація яких може змінюватись під впливом господарської діяльності. Специфічні показники характеризують вміст у воді забруднюючих речовин токсичної й радіаційної дії $[3,4]$. При обстеженні р. Дністер на території НПП «Подільські Товтри» виявлено інтенсивний шлейф скидів стічних вод, що підтверджено інтенсивним процесом евтрофікації та підвищеними показниками рівня $\mathrm{pH}$ і кислотності (рис. 3).

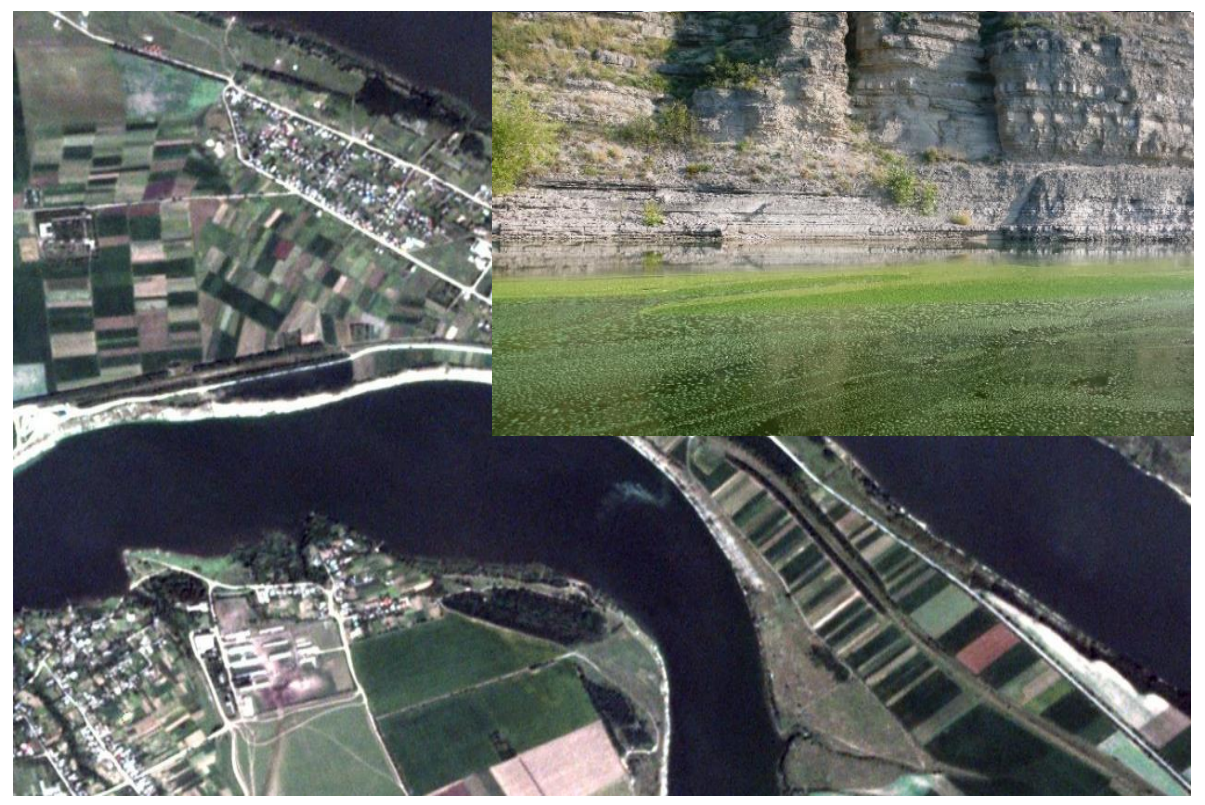

Рис. 3 - Місце скиду забруднених стічних вод р. Дністер НПП «Подільські Товтри», зафіксоване при натурних дослідженнях та на космічному знімку із супутника Sentinel від 14.08.2018 (роздільна здатність 3 м) час:11:40 
Проведено відбір та вивчення донних відкладів досліджуваного водного об'єкта. Донні відклади були вивчені за візуальною оцінкою. У гідрологічний журнал експедиції були занесені дані про тип донних відкладів, їх колір і запах, характер донних відкладів прибережної частини, які не можна захопити лотом (каміння, гравій, галька); консистенцію відкладів (щільні, пухкі, рідкі), наявність включень рослинних і тваринних решток, черепашок молюсків тощо (рис. 4).
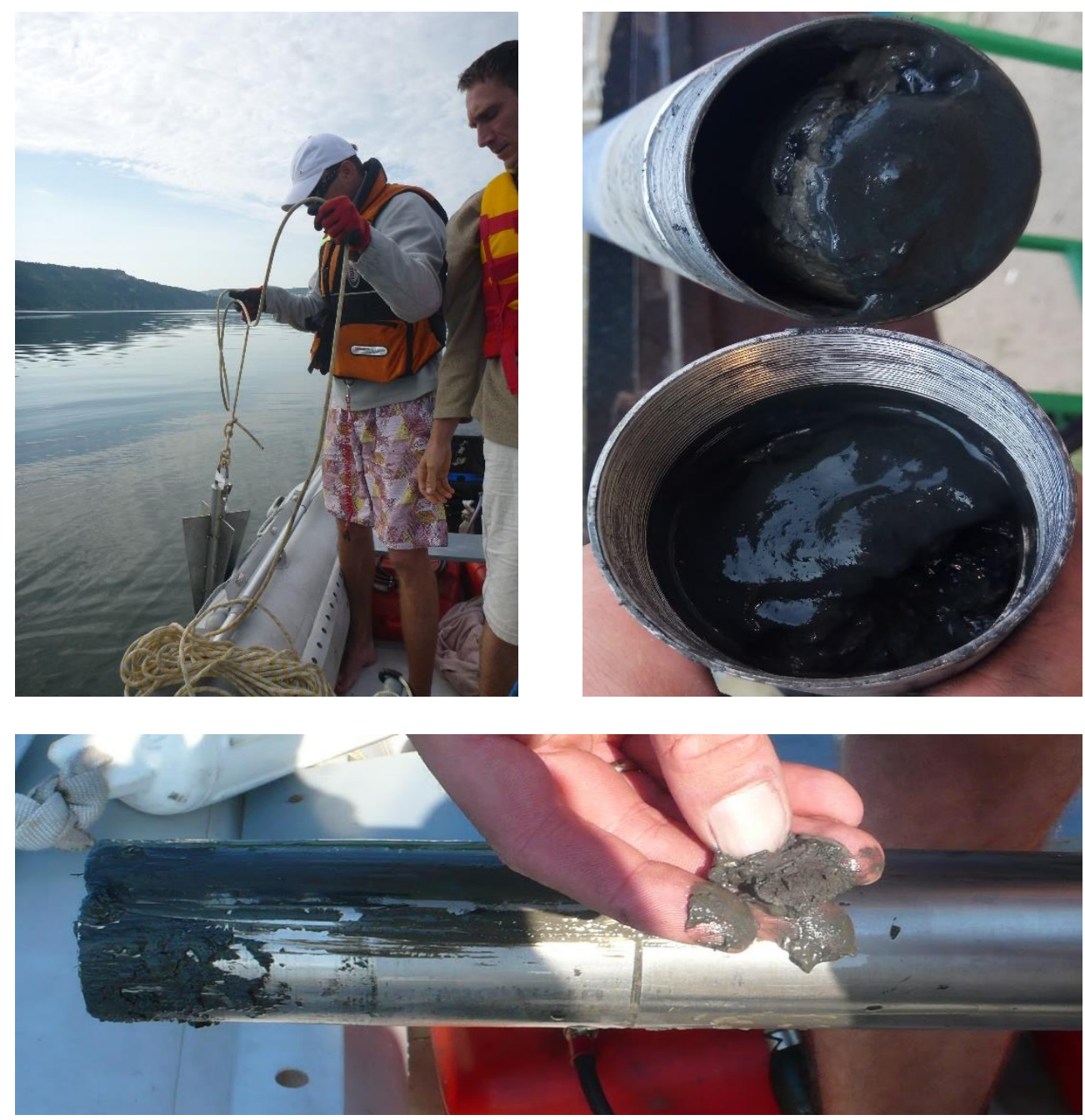

Рис. 4 - Відбір донних відкладів в акваторії затоки Бакота

Здійснено первинне вимірювання глибини, рельєфу дна та структури донних відкладів Бакоти. Методика проведення ехолокаційної батиметрії описана авторами в роботах [7, 10]. За результатами вимірів максимальна зафіксована глибина озера склала 38 м. Мінімальна 3 огляду на інформативність кількість точок вимірювань (з віддаллю між ними 500 м) перевищує сотню, робочий шлях без урахування підходів на потрібні курси становить близько 200 км, а кількість проб води вимірюється тисячами. Здійснено просторову прив'язку вимірювань, що дає змогу проводити коректне 
поповнення баз даних та подання результатів вимірювань у форматі, придатному для використання у ГІС. Для проведення батиметричної зйомки о. Бакота використано надувний гумовий човен «Brig Baltic» KIB - 5510K 3 двигуном «Mercury 25M SeaPro», на якому встановлено ехолот Lowrance: «LMS-527CDF IGPS». Робоча частота випромінювача звукових хвиль ехолота становить 200 кГц. Частота оновлення сигналу GPS-приймача 10 Гц. Об'єм кожного ехолотного профілю становить від 5 до 30 тис. вимірюваних значень, в залежності від частоти i часу запису в один файл. Кожне значення $є$ інформацією про координати точки зйомки, глибину, дату і час ехолотного проміру, температуру поверхні води, зміщення відносно попередньої точки проміру та містить іншу допоміжну інформацію. У процесі обробки використовуються лише значення координат і глибин. Вибірка значень виконується так, щоб на кожен квадратний метр площі озера припадало одне усереднене значення глибини.

Здійснено просторову прив'язку вимірювань, що дає змогу проводити коректне поповнення баз даних та подання результатів вимірювань у форматі, придатному для використання у ГІС. Особливу увагу приділено математичному моделюванню, побудові 3D моделей досліджуваної території для прогнозування небезпечних процесів, що відбуваються в навколишньому природному середовищі, прогнозу тенденцій і темпів змін екологічного стану, а також створенню бази геоінформаційної системи оцінки рівня техногенних забруднень, яка орієнтована на підтримку рішень 3 питань охорони i раціонального використання природних ресурсів.

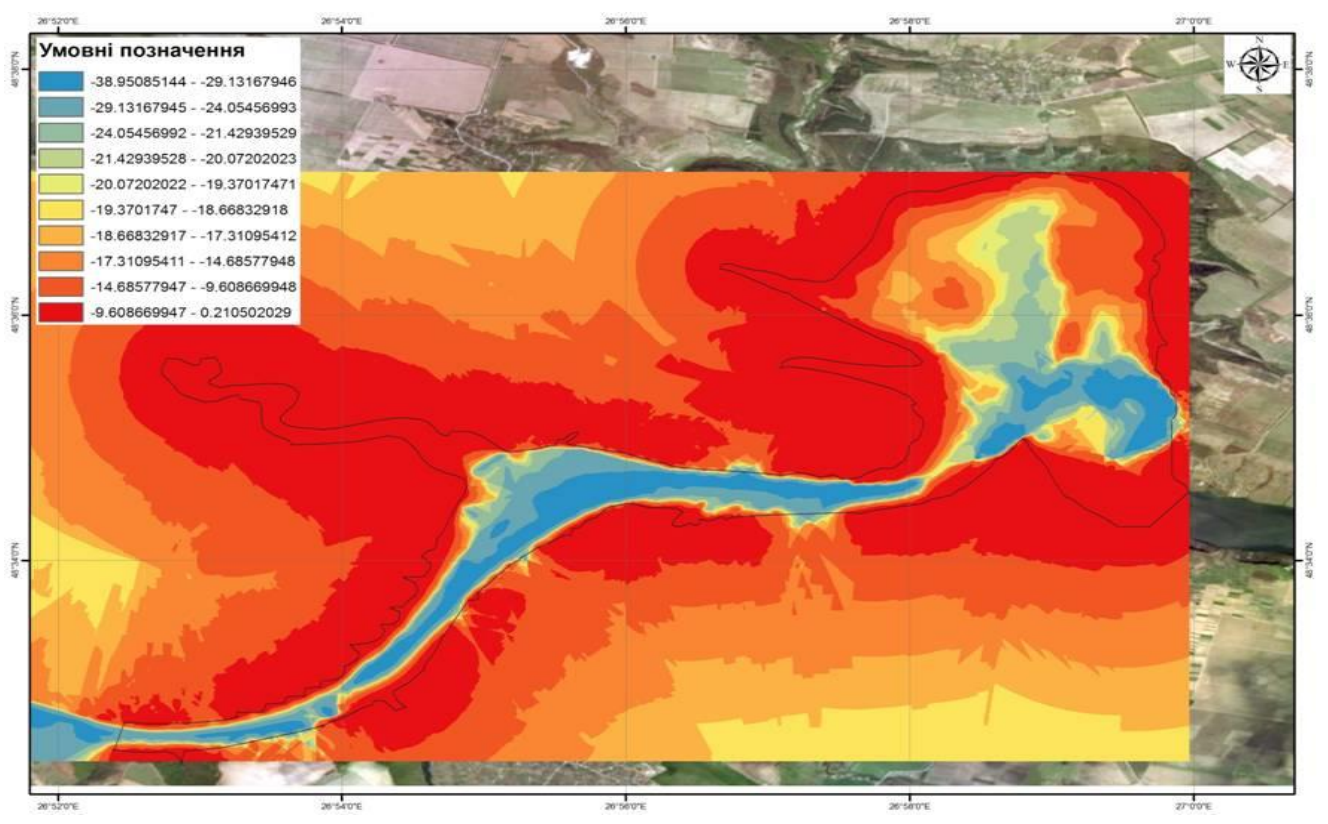

a) Обробка ехолокаційних даних модулем Geostatistical Analist 


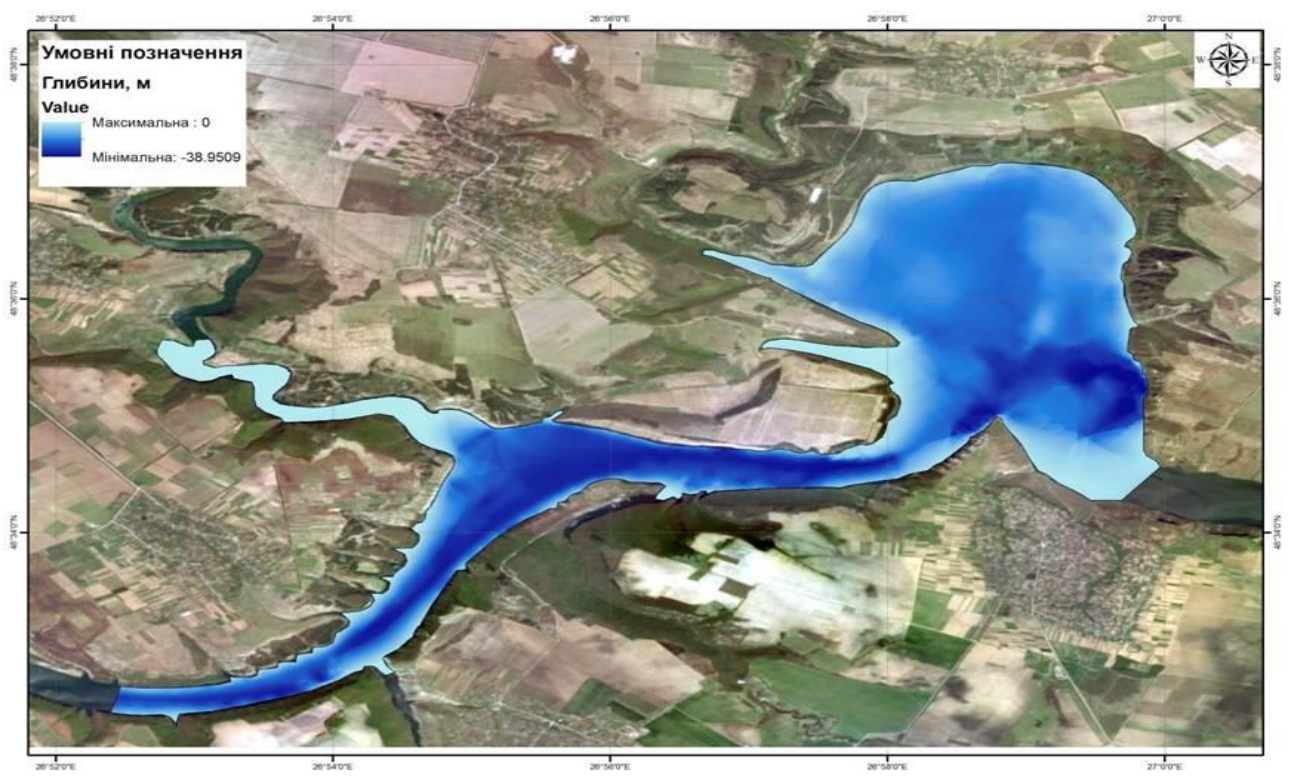

б) Створення GRID-моделі на основі гідролокаційних даних

Рис. 5 - Результати обробки даних в програмному середовищі ArcGis, які отримані за допомогою методу гідролокації затоки Бакота (a, б)

\section{Висновки та практичне значення результатів дослідження}

У результаті проведених досліджень обгрунтовано підходи, методи та науково-методологічні основи комплексного оцінювання інтенсивності i характеру антропогенного впливу на стан локальної геоекосистеми. За результатами первинних досліджень та проведеної ехолокації розроблено електронні батиметричні карти та 3D-моделі глибин затоки «Бакота», що дозволить створити безпечні умови судноплавства. Встановлено, що моніторинг глибин є важливою задачею для розв'язання проблем, пов'язаних з природоохоронними функціями водно-болотних угідь, що мають міжнародне значення, i прилеглих територій в контексті прогнозованого впливу запланованого будівництва каскаду малих ГЕС в межах Дністровського каньйону. При цьому від затоплень і підтоплень можуть постраждати не лише природоохоронні об'єкти з унікальними екосистемами, що підлягають захисту, а й численні поселення, що тяжіють до Дністра. Також регіональний підйом рівня води в долині р. Дністер призведе до підтоплення земель рівнинного лівобережжя 3 погіршенням якості грунтових вод як головного джерела питно-господарського водопостачання. У ході досліджень виявлено перспективи для подальших досліджень та можливості коректури карт за допомогою наземних та даних ДЗ3, використовуючи інструментарій ГІСтехнологій. 


\section{СПИСОК ЛІТРАТУРИ}

1. Паспорт водно-болотного угіддя міжнародного значення «Бакотська затока» сертифікат №1396 від 29.07.2004 p.

2. The Global Risks Report 2018, $13^{\text {th }}$ Edition // World Economic Forum. - Geneva. - 2018. $80 \mathrm{p}$.

3. Стратегія національної безпеки України [https://zakon.rada.gov.ua/laws/ show/105/2007].

4. Техноекологія: навч. посіб. для студ. вищ. навч. закл. / В.М. Удод, В.В. Трофімович, О.С. Волошкіна, О.М. Трофимчук // КНУБА, Ін-т телекомунікацій і глобального інформаційного простору НАНУ. - К., 2007. - 195 с.

5. Красовський Г.Я. Космічний моніторинг безпеки водних екосистем із застосуванням геоінформаційних технологій. - К.: Інтертехнологія, 2008. - 480 с.

6. Інформатизація аерокосмічного землезнавства / В.І. Лялько, С.О. Довгий, О.М. Трофимчук [та ін.]; НАН України, Ін-т геол. наук, Центр аерокосм. досліджень Землі [та ін.]. - К. : Наук. думка, 2001. - 606 с.

7. Інформаційне забезпечення гідроакустичного моніторингу озер Західного Полісся [Трофимчук О.М., Мокрий В.І., Радчук В.В., Радчук I.В., Загородня С.А.] // Екологічна безпека та природокористування - К., 2015. - Вип. 1(17) - С. 5-15.

8. Загородня С.А. Геоінформаційні технології для екологічної оцінки природнозаповідних територій / С.А. Загородня // Екологічна безпека та природокористування. 2016 - № 22 - С. 87-94.

9. Моніторинг навколишнього середовища 3 використанням космічних знімків супутника NOAA / [О.М. Трофимчук, В.В. Радчук, Г.Я. Красовський, І.В. Радчук] // Під ред. С.О. Довгого. - К., ФОП Пономаренко С.В., 2013, 316 с.

10. GIS-Based assessment of antropogenic influence in Western Polissya region Limnological ecosystems [Zagorodnya S.A., Novokhatska N.A., Okhariev V.O., Popova M.A., Radchuk I.V., Trysnyuk T.V., Shumeiko V.O., Atrasevych O.V] // Екологічна безпека та природокористування - К., 2018. - Вип. 2(26). - С. 23-34.

Стаття надійшла до редакиії 06.05.2019 і прийнята до друку після рещензування 05.06.2019

\section{REFERENCES (TRANSLATED AND TRANSLITERATED)}

1. Pasport vodno-bolotnogo ugiddja mizhnarodnogo znachennja «Bakots'ka zatoka» (2004). [Sertyfikat №1396] (in Ukrainian).

2. The Global Risks Report 2018. (2018). In World Economic Forum (13th ed., 80 p.). Geneva.

3. Strategija nacional'noi' bezpeky Ukrai'ny: Decree of the President of Ukraine. (February 12, 2007). Retrieved from https://zakon.rada.gov.ua/laws/show/105/2007 (in Ukrainian).

4. Udod, V. M., Trofimovych, V. V., Voloshkina, O. S., \& Trofymchuk, O. M. (2007). Tehnoekologija: Navch. posib. dlja stud. vyshh. navch. zakl. Kyiv: KNUBA, In-t telekomunikacij i global'nogo informacijnogo prostoru NANU (in Ukrainian).

5. Krasovs'kyj, G. J. (2008). Kosmichnyj monitoryng bezpeky vodnyh ekosystem iz zastosuvannjam geoinformacijnyh tehnologij. Kyiv: Intertehnologija (in Ukrainian).

6. Ljal'ko, V. Y., Dovgyj, S. O., \& Trofymchuk, O. M. (2001). Informatyzacija aerokosmichnogo zemleznavstva. Kyiv: Naukova dumka (in Ukrainian).

7. Trofymchuk, O. M., Mokryi, V. I., Radchuk, V. V., Radchuk, I. V., \& Zagorodnya, S. A. (2015). Information support of hydroacoustic monitoring of the Western Polesie lakes. Environmental Security and Natural Resources, 1(17), 5-14 (in Ukrainian).

8. Zagorodnya, S. A. (2016). Geographic information technology for environmental assessment natural-protected areas. Environmental Safety and Natural Resources, 3-4(22), 87-93 (in Ukrainian). 
9. Trofymchuk, O. M., Radchuk, V. V., Krasovs'kyj, G. Y., \& Radchuk, I. V. (2013). Monitoryng navkolyshn'ogo seredovyshha z vykorystannjam kosmichnyh znimkiv suputnyka NOAA (S. O. Dovgiy, Ed.). Kyiv: FOP Ponomarenko Je.V. (in Ukrainian).

10.Zagorodnya, S., Novokhatska, N., Okhariev, V., Popova, M., Radchuk, I., Trysnyuk, T., Shumeiko, V., \& Atrasevych, O. (2018). GIS-based assessment of anthropogenic influence in Western Polissya region limnological ecosystems. Environmental Safety And Natural Resources, 26(2), 23-33. doi:http://dx.doi.org/10.32347/2411-4049.2018.2.23-33

The article was received 06.05.2019 and was accepted after revision 05.06.2019

\section{Трофимчук Олександр Миколайович}

член-кореспондент Національної академії наук України, доктор технічних наук, професор, директор Інституту телекомунікацій i глобального інформаційного простору НАН України

Адреса робоча: 03186 Україна, м. Київ, Чоколівський бульвар, 13

e-mail: itelua@kv.ukrtel.net

ORCID ID 0000-0003-3782-4209

\section{Красовський Григорій Якович}

доктор технічних наук, професор, завідувач кафедри геоінформаційних технологій i космічного моніторингу Землі Національного аерокосмічного університету ім. М.С. Жуковського

\section{Радчук Валентин Васильович}

доктор геологічних наук, завідувач відділом досліджень навколишнього середовища Інституту телекомунікацій і глобального інформаційного простору НАН України

\section{Триснюк Василь Миколайович}

доктор технічних наук, завідувач відділом досліджень навколишнього середовища Інституту телекомунікацій і глобального інформаційного простору НАН України

Адреса робоча: 03186 Україна, м. Київ, Чоколівський бульвар, 13

e-mail: trysnyuk@ukr.net

ORCID ID: 0000-0001-9920-4879

\section{Радчук Ігор Валентинович}

кандидат технічних наук, старший науковий співробітник відділу досліджень навколишнього середовища Інституту телекомунікацій і глобального інформаційного простору НАН України

Адреса робоча: 03186 Україна, м. Київ, Чоколівський бульвар, 13

e-mail: igor.radchuk.v@gmail.com

ORCID ID: 0000-0003-4999-1258

\section{Крета Дмитро Леонідович}

кандидат технічних наук, старший науковий співробітник відділу досліджень навколишнього середовища Інституту телекомунікацій і глобального інформаційного простору НАН України

Адреса робоча: 03186 Україна, м. Київ, Чоколівський бульвар, 13

e-mail:dim.leo@gmail.com

ORCID ID 0000-0001-5897-0008 


\section{Загородня Сніжана Анатоліївна}

кандидат технічних наук, старший науковий співробітник відділу досліджень навколишнього середовища Інституту телекомунікацій і глобального інформаційного простору НАН України

Адреса робоча: 03186 Україна, м. Київ, Чоколівський бульвар, 13

e-mail:zagorodnya.s@gmail.com

ORCID ID: 0000-0002-4332-4211

\section{Шевякіна Наталя Анатоліївна}

кандидат технічних наук, старший науковий співробітник відділу досліджень навколишнього середовища Інституту телекомунікацій і глобального інформаційного простору НАН України

Адреса робоча: 03186 Україна, м. Київ, Чоколівський бульвар, 13

e-mail: novokhatska.natalia@gmail.com

ORCID ID: 0000-0002-5984-5580

\section{Охарєв Вячеслав Олександрович}

кандидат технічних наук, старший науковий співробітник відділу природних ресурсів Інституту телекомунікацій і глобального інформаційного простору НАН України

Адреса робоча: 03186 Україна, м. Київ, Чоколівський бульвар, 13

e-mail: okhariev.vo@gmail.com

ORCID ID: 0000-0001-6270-6293

\section{Триснюк Тарас Васильович}

кандидат технічних наук, науковий співробітник відділу прикладної математики Інституту телекомунікацій і глобального інформаційного простору НАН України

Адреса робоча: 03186 Україна, м. Київ, Чоколівський бульвар, 13

e-mail: trysnyuk@ukr.net

ORCID ID: 0000-0002-3672-8242

\section{Шумейко Віктор Олександрович}

кандидат технічних наук, викладач Інституту телекомунікацій i глобального інформаційного простору НАН України

Адреса робоча: 03186 Україна, м. Київ, Чоколівський бульвар, 13

e-mail: shym1983@ukr.net

ORCID ID: 0000-0002-0285-4566

\section{Атрасевич Олександр Валентинович}

аспірант Інституту телекомунікацій і глобального інформаційного простору НАН України

Адреса робоча: 03186 Україна, м. Київ, Чоколівський бульвар, 13

e-mail:atras@ukr.net

ORCID ID: 0000-0001-7703-8494

\section{Вишняков Вячеслав Юрійович}

кандидат технічних наук, начальник відділу обробки даних ДЗ3 Центру прийому і обробки спеціальної інформації та контролю навігаційного поля

e-mail:wishnya_dzz@ukr.net

ORCID ID: 0000-0003-2057-0505 